\title{
Chagas Disease Diagnosis Using Polymerase Chain Reaction, Hemoculture and Serologic Methods
}

\author{
Egler Chiari \\ Departamento de Parasitologia, Instituto de Ciências Biológicas, Universidade Federal de Minas Gerais and \\ Unicentro Newton Paiva, Caixa Postal 486, 31270-901 Belo Horizonte, MG, Brasil
}

Key words: Chagas disease - diagnosis - polymerase chain reaction - hemoculture

Different approaches have been used in the diagnosis of chronic Chagas disease. Serologic tests are used to detect antibodies against Trypanosoma cruzi and not the presence of the parasite itself. These tests have high sensitivity but lack specificity because of antigenic cross-reactivity with parasites such as Leishmania sp. and $T$. rangeli (Schmunis 1991, Saldana \& Sousa 1996). Parasitological tests such as hemoculture or xenodiagnosis have proven to be highly specific, but the sensitivity of these techniques is low. Recently, molecular assays such as the polymerase chain reaction (PCR), which amplify certain repetitive sequences of trypanosome kinetoplast DNA (kDNA) have been proposed as a good alternative too for detection of $T$. cruzi in human blood (Avila et al. 1993, Wincker et al. 1994, Britto et al. 1995a). The $\approx 330$-base pair (bp) fragment of the kinetoplast minicircles is normally used as a target for amplification.

The PCR assay has shown a variable degree of efficiency. Initial sensitivity reports ranged from $96 \%$ to $100 \%$ compared with serologic diagnosis (Avila et al. 1993, Wincker et al. 1994). A lower sensitivity level was observed by different researchers (Britto et al. 1995b, Junqueira et al. 1996). These inconsistencies illustrate the need for additional evaluation of large numbers of chagasic individuals from different endemic regions in Brazil due to extensive variations in the incidence and clinical manifestations of Chagas disease in this country.

A new technique to verify cure in chagasic patients who received specific treatment is needed. Conventional serologic tests such as the indirect immunofluorescence (IIF) test, the indirect hemagglutination test, and the ELISA are ineffective because they are persistently positive in most treated

Fax.: +55-31-499.2847. E-mail: chiari@icb.ufmg.br Received 9 June 1999

Accepted 9 August 1999 patients even when parasitologic test results are negative (Krettli et al. 1984). Since current parasitologic methods have low sensitivity, a negative result does not necessarily mean that the individual is free of infection. Krettli and Brener (1982) proposed complement-mediated lysis (CoML), which detects lytic antibodies, as an alternative method. The presence of these antibodies indicates an active infection and the absence indicates cure (Krettli et al. 1982).

However, CoML is labor-intensive and timeconsuming because it requires living trypomastigotes, human serum as a complement source, and counting numerous parasites by light microscopy.

In this report we compared an optimized PCR technique with hemoculture (Chiari et al. 1989) and CoML (Galvão et al. 1993) in detecting T. cruzi infection in individuals from different endemic and nonendemic regions of Brazil who had conventional serologic results that were either positive, negative, or inconclusive. An optimized PCR method was used on DNA isolate from blood of infected and uninfected individuals from endemic and nonendemic areas. This PCR protocol has a sensitivity of $0.1 \%$ of kDNA after hybridization with specific probe, which corresponds to one intact parasite or $0.01 \%$ of the T. cruzi DNA fragment circulating in the blood of an infected host. The 330-bp and 750-bp specific products were detected in subjects who had positive serology and hemoculture results and in those with positive serology and negative hemoculture results. An additional amplified DNA fragment of $199 \mathrm{bp}$ derived from human DNA (Gomes et al. 1998) was also found in positive and negative T. cruzi samples and was used as an internal control of PCR inhibition. In samples with the DNA concentration very low, we identified PCR-amplified DNA using slot-blot hybridization with an alkaline phosphatase-labeled probe (Gomes et al. 1998). The PCR diagnosis was performed on 126 samples from individuals from endemic (113) and nonendemic (13) areas. The PCR amplification yielded positive results in $83.5 \%$ (66 of 79) of individuals with positive serology, 
$47.6 \%$ (10 of 21) with negative serology, and $46.2 \%$ (6 of 13) with inconclusive serology. Of ten individuals with negative serology and positive PCR result, eight (80\%) had positive CoML, indicating that they could have been chagasic but were not mounting immune responses. The PCR results were also positive for all individuals who had positive hemoculture, for 37 individuals with negative hemoculture and positive serology and for two of six individuals with inconclusive serology and negative hemoculture. Thirteen individuals living in nonendemic areas who had negative serology were used as a negative control group: $100 \%$ had negative PCR results (Gomes et al. 1999). Our results show that the optimized PCR protocol used here was very sensitive in detecting the presence of $T$. cruzi in chronic chagasic patients. The PCR and CoML results were well correlated in all of the groups studied. These results suggest a need for future analysis of two approaches. Specifically, two issues need to be addressed. The first is to verify the usefulness of the PCR as a tool to assess cure after specific chemotherapy. Experiments are in progress in our laboratory to ascertain the efficiency of our PCR protocol in monitoring cure after specific treatment. The second question involves positive PCR results observed for individuals with negative serologic results. This could be clarified through extensive analysis of the PCR and other Chagas disease diagnostic methods in blood donor screening.

\section{REFERENCES}

Avila H, Borges-Pereira J, Thiemann O, De Paiva E, Degrave W, Morel CM, Simpson L 1993. Detection of Trypanosoma cruzi in blood specimes of chronic chagasic patients by polymerase chain reaction amplification of kinetoplast minicircle DNA: comparison with serology and xenodiagnosis. J Clin Microbiol 31: 2421-2426.

Britto C, Cardoso MA, Vanni CMM, Hasslocher-Moreno A, Xavier S, Oeleman W, Santoro A, Pimimez C, Morel CM, Wincker P 1995a. Polymerase chain reaction detection of Trypanosoma cruzi in human blood samples as a tool for diagnosis and treatment evolution. Parasitology 110: 241-247.

Britto C, Cardoso MA, Ravel C, Santoro A, BorgesPereira J, Coura JR, Morel CM, Wincker P 1995b.
Trypanosoma cruzi: Parasite detection and strain discrimination in chronic chagasic patients from northeastern Brazil using amplification of Kinetoplast DNA and nonradioactive hybridization. Exp Parasitol 81: 462- 471.

Chiari E, Dias JCP, Lana M, Chiari CA 1989. Hemocultures for the parasitological diagnosis of human chronic Chagas disease. Rev Soc Bras Med Trop 22: 19-23.

Galvão LMC, Nunes RMB, Cançado JR, Brener Z, Krettli AU 1993. Lytic antibody titre as a means of assessing cure after treatment of Chagas disease: a 10 years follow-up study. Trans $R$ Soc Trop Med Hyg 87: 220-223.

Gomes ML, Macedo AM, Vago AR, Pena SDJ, Galvão LMC, Chiari E 1998. Trypanosoma cruzi: Optimization of polymerase chain reaction for detection in human blood. Exp Parasitol 88: 28-33.

Gomes ML, Galvão LMC, Macedo AM, Pena SDJ, Chiari E 1999. Chagas disease diagnosis: Comparative analysis of parasitologic, molecular, and serologic methods. Am J Trop Med Hyg 60: 205-210.

Junqueira ACV, Chiari E, Wincker P 1996. Comparison of the polymerase chain reaction with two classical parasitological methods for the diagnosis of Chagas disease in an endemic region of north-eastern Brazil. Trans R Soc Trop Med Hyg 90: 129-132.

Krettli AU, Brener Z, 1982. Resistance against Trypanosoma cruzi associated to anti-living trypomastigote antibodies. J Immunol 129: 2009-2012.

Krettli AU, Cançado JR, Brener Z 1984. Criterion of cure of human Chagas disease after specific chemotherapy: recent advances. Mem Inst Oswaldo Cruz. 79: 157-164.

Krettli AU, Cançado JR, Brener Z 1982. Effect of specific chemotherapy on the levels of lytic antibodies in Chagas disease. Trans $R$ Soc Trop Med Hyg 76: 334-340.

Saldana A, Sousa OE 1996. Trypanosoma rangeli: epimastigote immunogenicity and cross-reaction with Trypanosoma cruzi. J Parasitol 82: 363-366.

Schmunis GA 1991. Trypanosoma cruzi, the ethiological aethiological agent of Chagas disease: status in blood supply in endemic countries. Transfusion 31: 547557.

Wincker P, Britto C, Borges-Pereira J, Cardoso MA, Oeleman W, Morel CM 1994. Use of a simplified polymerase chain reaction procedure to detect Trypanosoma cruzi in blood samples from chronic chagasic patients in a rural endemic area. Am J Trop Med Hyg 51: 771-777. 